CZASOPISMO INŻYNIERII LĄDOWEJ, ŚRODOWISKA I ARCHITEKTURY JOURNAL OF CIVIL ENGINEERING, ENVIRONMENT AND ARCHITECTURE

JCEEA, t. XXXIII, z. 63 (3/16), lipiec-wrzesień 2016, s. 525-532

\author{
Barbara WLODARCZYK ${ }^{1}$ \\ Paweł P. WŁODARCZYK ${ }^{2}$
}

\title{
MIKROBIOLOGICZNE OGNIWO PALIWOWE Z KATODĄ Cu-B
}

\begin{abstract}
Elektrody w mikrobiologicznych ogniw paliwowych najczęściej wykonywane są $\mathrm{z}$ tkaniny węglowej, czasami z 1\% dodatkiem platyny. Praca przedstawia analizę możliwości wykorzystania stopu $\mathrm{Cu}-\mathrm{B}$ jako katalizatora katody. Metodyka obejmuje przygotowanie katalizatora, analizę jego aktywności w redukcji $\mathrm{H}_{2} \mathrm{O}_{2}$ oraz porównanie zmian stężenia ChZT, $\mathrm{NH}_{4}^{+}$oraz $\mathrm{NO}_{3}^{-}$podczas oczyszczania ścieków komunalnych $\mathrm{w}$ reaktorze $\mathrm{z}$ napowietrzaniem oraz przy wykorzystaniu mikrobiologicznego ogniwa paliwowego z katodą Cu-B. Czas redukcji ChZT przy wykorzystaniu mikrobiologicznego ogniwa paliwowego z katodą $\mathrm{Cu}-\mathrm{B}$ jest zbliżony do czasu redukcji przy napowietrzaniu. Uzyskana w ogniwie gęstość prądu $\left(0,21 \mathrm{~mA} / \mathrm{cm}^{2}\right)$ oraz ilość energii elektrycznej jest niewielka $(0,87 \mathrm{Wh})$, jednak pomiary przeprowadzono w reaktorach o pojemności 15 l. Uzyskana ilość energii pozwala jednak na eliminację energii koniecznej do napowietrzania zbiorników. Badania wykazały, więc że istnieje możliwość wykorzystania stopu $\mathrm{Cu}-\mathrm{B}$ jako katalizatora katody mikrobiologicznego ogniwa paliwowego.
\end{abstract}

Słowa kluczowe: mikrobiologiczne ogniwo paliwowe, katalizator, stop $\mathrm{Cu}-\mathrm{B}$, katoda, inżynieria środowiska, odnawialne źródła energii

\section{Wprowadzenie}

Stały wzrost gospodarczy powoduje generowanie ogromnych ilości odpadów, które stanowić mogą cenny surowieć do pozyskiwania energii [1]. Taki sposób podejścia do wszelkiego rodzaju substancji odpadowych, stanowić będzie z pewnością przyszłościowe rozwiązanie w każdej dziedzinie gospodarki. Silnie rozwijającą się technologią oczyszczania ścieków przy jednoczesnym generowaniu energii elektrycznej jest technologia mikrobiologicznych ogniw paliwowych (MFC - microbial fuel cell) $[1,2]$. Technologia ta wykorzystuje bezpośrednią

\footnotetext{
${ }^{1}$ Autor do korespondencji / corresponding author: Barbara Włodarczyk, Uniwersytet Opolski, Wydział Przyrodniczo-Techniczny, Samodzielna Katedra Inżynierii Procesowej, ul. Dmowskiego 7-9, 45-365 Opole; tel. 77 4016717; barbara.wlodarczyk@uni.opole.pl

2 Paweł P. Włodarczyk, Uniwersytet Opolski, Wydział Przyrodniczo-Techniczny, Samodzielna Katedra Inżynierii Procesowej, ul. Dmowskiego 7-9, 45-365 Opole; tel. 77 4016706; pawel.wlodarczyk@uni.opole.pl
} 
przemianę materii organicznej zgromadzonej w odpadach przy udziale mikroorganizmów [2-5]. Mikroorganizmy odżywiając się ściekami jednocześnie generują jony $\mathrm{H}^{+}$[6-9]. Głównym parametrem określającym funkcjonowanie MFC jest spadek stężenia ChZT w ściekach [2, 10, 11]. Praca MFC jest wynikiem procesów zachodzących na elektrodach. Najczęściej stosowanym materiałem na elektrody jest tkanina węglowa, często z 1\% dodatkiem Pt [1]. Ze względu na niską gęstość prądu generowaną przez obecnie wykorzystywane MFC konieczne jest poszukiwanie nowych materiałów na elektrody (katalizatory). Praca przedstawia badania możliwości wykorzystania stopu Cu-B jako katalizatora elektrody tlenowej (katody).

\section{Materiały i metodyka}

\subsection{Materiał badawczy}

Pierwszym etapem było przygotowanie katody. Stop $\mathrm{Cu}-\mathrm{B}$ naniesiono na siatkę miedzianą metodą elektrochemiczną. Siatkę przed naniesieniem stopu odpowiednio przygotowano [12]. Następnie przygotowano mieszaninę której skład przedstawiono w tabeli 1 [12, 13]. Stopy otrzymano w temperaturze 365K [14]. Uzyskano stopy o różnym procentowym udziale B. Udział ten określono metodą rentgenograficzną.

Tabela 1. Skład elektrolitu do uzyskania stopu $\mathrm{Cu}-\mathrm{B}$ [opracowanie własne]

Tabela 2. Parametry analizowanych ścieków Table 1. Electrolyte composition for the preparation of $\mathrm{Cu}-\mathrm{B}$ alloy [own compilation] [opracowanie własne

Table 2. Parameters of analysed wastewater [own compilation]

\begin{tabular}{cc}
\hline składnik & ilość $[\mathbf{m o l} / \mathbf{l}]$ \\
\hline $\mathrm{CuSO}_{4} \cdot 7 \mathrm{H}_{2} \mathrm{O}$ & 0,05 \\
\hline $\mathrm{NaBH}_{4}$ & 0,02 \\
\hline $\mathrm{NaOH}$ & 1,00 \\
\hline Trilon B & 0,12 \\
\hline
\end{tabular}

\begin{tabular}{cc}
\hline parametr & wielkość \\
\hline $\mathrm{pH}$ & 6,6 \\
\hline $\mathrm{ChZT}[\mathrm{mg} / \mathrm{l}]$ & 2101 \\
\hline $\mathrm{NH}_{4}{ }^{+}[\mathrm{mg} / \mathrm{l}]$ & 15 \\
\hline $\mathrm{NO}_{3}{ }^{-}[\mathrm{mg} / \mathrm{l}]$ & 5 \\
\hline
\end{tabular}

Funkcjonowanie mikrobiologicznego ogniwa paliwowego z katodą $\mathrm{Cu}-\mathrm{B}$ określono na podstawie szybkości redukcji ChZT, $\mathrm{NH}_{4}{ }^{+}$oraz $\mathrm{NO}_{3}{ }^{-} \mathrm{W}$ ściekach komunalnych z osadem czynnym. Parametry ścieków do badań przedstawiono w tabeli 2.

\subsection{Stanowisko pomiarowe}

W pierwszej kolejności określono aktywność katalityczną uzyskanych stopów na podstawie szybkości rozkładu $\mathrm{H}_{2} \mathrm{O}_{2}$ (analiza ilości wydzielanych gazów). Aktywność określono dla katalizatorów z różnym udziałem $\mathrm{B}$, a następnie wybrano stop o najwyższej aktywności rozkładu do dalszych badań funkcjonowania mikrobiologicznego ogniwa paliwowego. 
Następnie przeprowadzono pomiary zmiany stężeń ChZT, $\mathrm{NH}_{4}{ }^{+}$oraz $\mathrm{NO}_{3}{ }^{-}$ w ściekach komunalnych $\mathrm{z}$ osadem czynnym podczas ich oczyszczania w reaktorze zbiornikowym podczas napowietrzania oraz funkcjonowania mikrobiologicznego ogniwa paliwowego (z katodą $\mathrm{Cu}-\mathrm{B})[15,16]$. Pomiarów dokonano w temperaturze 293K w reaktorach o pojemności 15 litrów. Rysunki 1 i 2 przedstawiają schemat i widok stanowiska pomiarowego (reaktorów) do oczyszczania ścieków.

Napowietrzanie ścieków w pierwszym reaktorze zrealizowano wykorzystując pompę o mocy $5 \mathrm{~W}(270 \mathrm{l} / \mathrm{h})$. Natomiast $\mathrm{w}$ drugim reaktorze oczyszczano ścieki z wykorzystaniem MFC z katodą $\mathrm{Cu}-\mathrm{B}$. Na materiał anody wykorzystano tkaninę węglową. MFC było na stałe obciążone odbiornikiem prądu elektrycz-

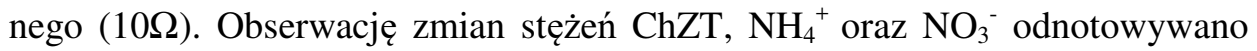
w czasie. W czasie pracy mikrobiologicznego ogniwa paliwowego dokonano również pomiaru mocy MFC.
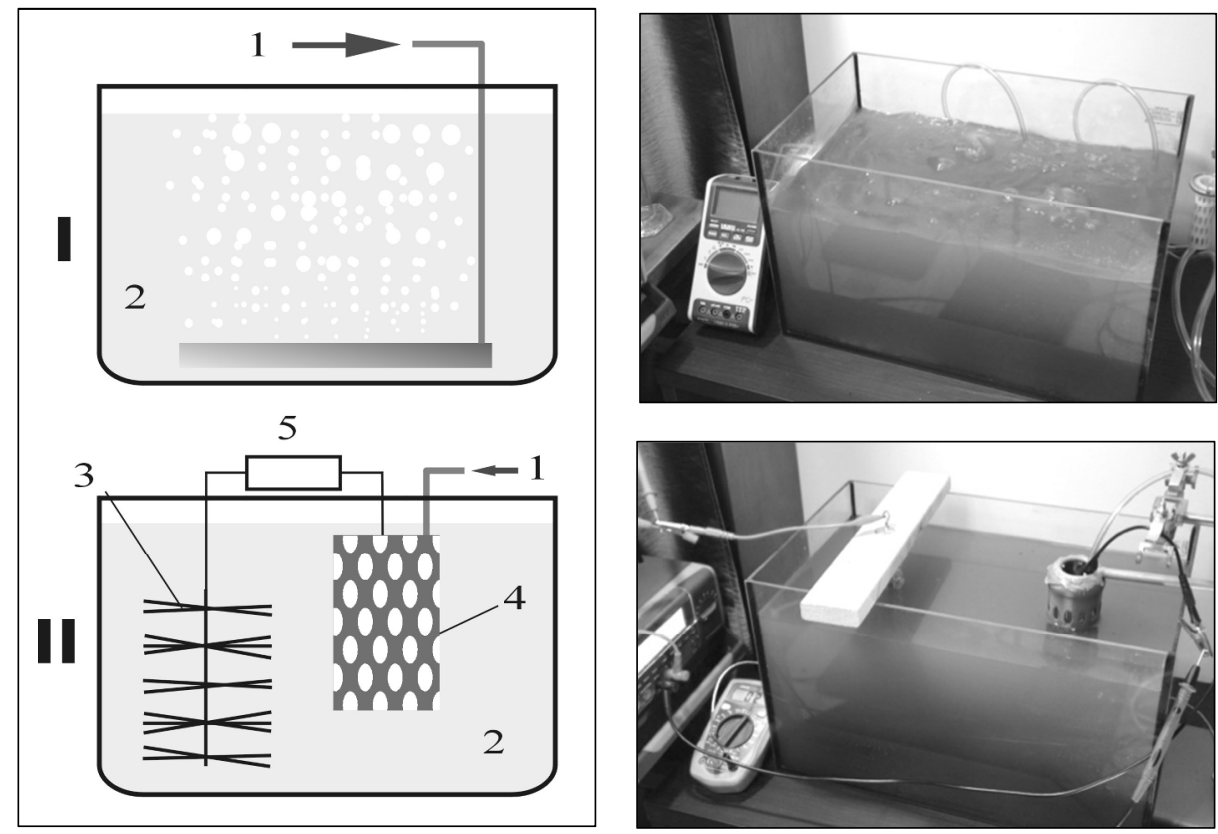

Rys. 1. Schemat stanowiska pomiarowego: I - z na- Rys. 2. Reaktor: I - z napowietrzaniem, powietrzaniem, II - przy wykorzystaniu mikrobiolo- II - z mikrobiologicznym ogniwem paliwogicznego ogniwa paliwowego $\mathrm{z}$ katalizatorem $\mathrm{Cu}-\mathrm{B}$ wym [opracowanie własne]

[opracowanie własne]; 1-powietrze, 2-ścieki, 3-anoda, Fig. 2. Reactor: I - with aeration, II - with 4-katoda (Cu-B) w osłonie ABS, 5-odbiornik prądu

Fig. 1. Scheme of measurement position: I - with MFC [own compilation] aeration, II - with using MFC [own compilation]; 1-air, 2-wastewater, 3-anode, 4-cathode (Cu-B) with ABS cover, 5 -electricity receiver 
Na rys. 3 przedstawiono konstrukcję katody z membraną wymiany protonowej (PEM) i osłonę z tworzywa ABS. Jako membranę PEM wykorzystano Nafion 117 [17], natomiast osłonę wykonano w technologii druku 3D (grubość warstwy $390 \mu \mathrm{m})$. Katoda była zanurzona w roztworze $\mathrm{KOH}$ i stale napowietrzana $\mathrm{Z}$ wydajnością $20 \mathrm{l} / \mathrm{h}$.

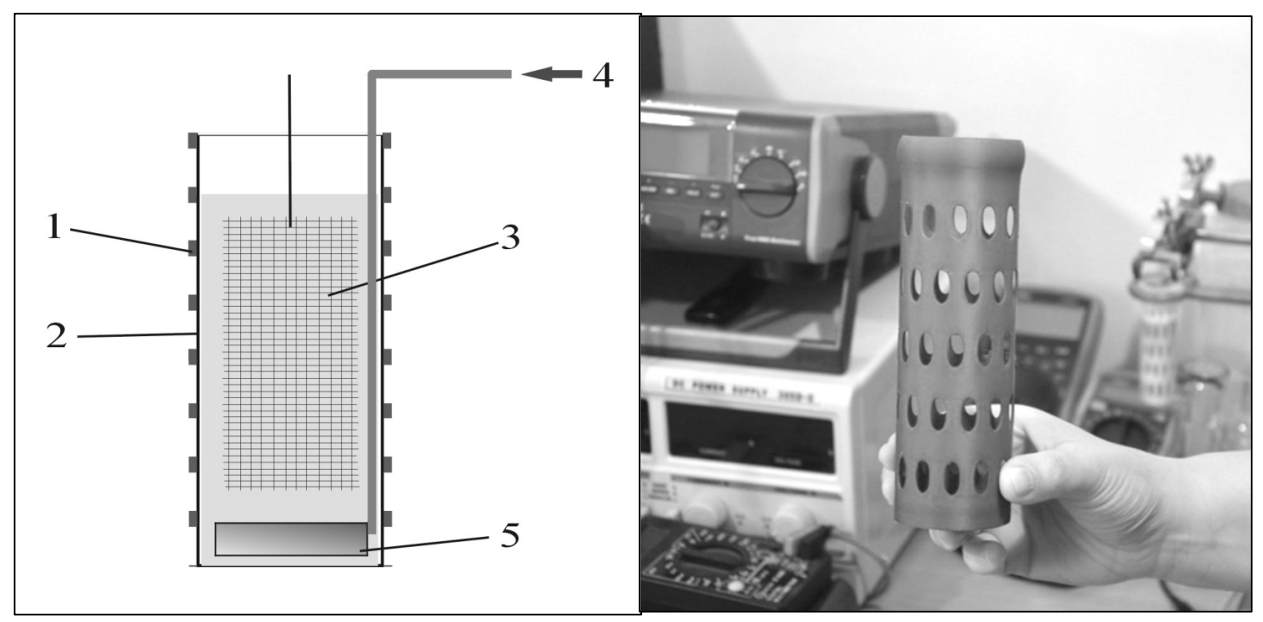

Rys. 3. Schemat katody w osłonie i widok osłony z tworzywa ABS [opracowanie własne] 1-osłona, 2-membrana PEM (Nafion), 3 - katoda Cu-B, 4-doprowadzenie powietrza, 5- bełkotka

Fig. 3. Scheme of cathode and view of ABS cover [own compilation]

1-cover, 2-PEM (Nafion), 3-Cu-B cathode, 4- air supply, 5-bubbler

\section{Wyniki badań}

Rysunek 4 przedstawia szybkość rozkładu $\mathrm{H}_{2} \mathrm{O}_{2}$ na katalizatorze $\mathrm{Cu}-\mathrm{B}$ w zależności od procentowego udziału B. Najwyższą aktywnością w procesie charakteryzuje się stop z 9\% udziałem B, który wybrano do dalszych pomiarów MFC. Rysunek 5 przedstawia krzywą spadku ChZT podczas oczyszczania ścieków w reaktorze z napowietrzaniem i z MFC z katodą $\mathrm{Cu}$-B. Przeprowadzone pomiary pozwoliły również na wyznaczenie zmian wartości stężeń $\mathrm{NH}_{4}{ }^{+}$oraz $\mathrm{NO}_{3}{ }^{-}$w trakcie procesu oczyszczania ścieków (rys. 6 i rys. 7).

Uzyskana średnia gęstość prądu w MFC w okresie 16 dni wyniosła $0,21 \mathrm{~mA} / \mathrm{cm}^{2}$. Natomiast całkowita ilość energii wyprodukowana w MFC w ciągu 16 dni wyniosła $0,87 \mathrm{Wh}$. 


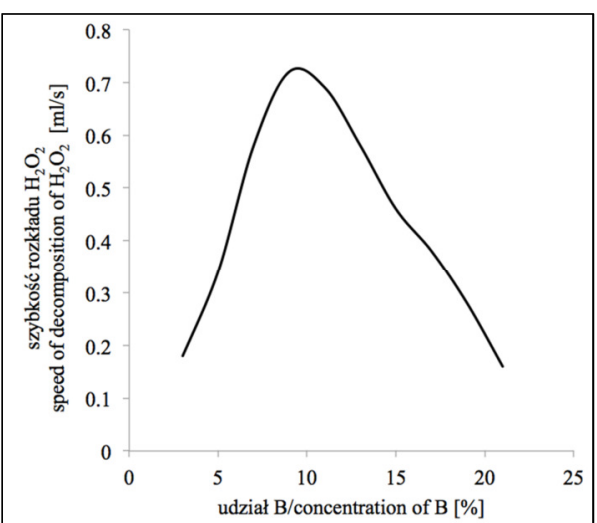

Rys. 4. Szybkość rozkładu $\mathrm{H}_{2} \mathrm{O}_{2}$ na katalizatorze $\mathrm{Cu}-\mathrm{B}$ w zależności od udziału $\mathrm{B}$ w stopie [opracowanie własne]

Fig. 4. Speed of $\mathrm{H}_{2} \mathrm{O}_{2}$ decomposition on $\mathrm{Cu}-\mathrm{B}$ catalyst depending on concentration of $\mathrm{B}$ in alloy [own compilation]

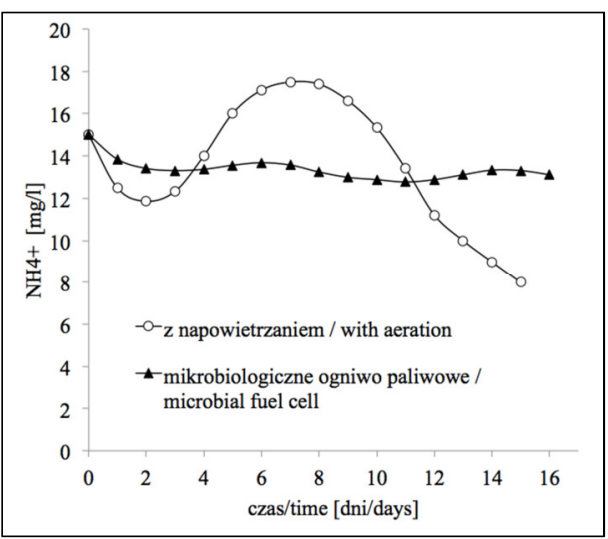

Rys. 6. Zmiana stężenia $\mathrm{NH}_{4}^{+}$podczas oczyszczania ścieków z napowietrzaniem oraz przy wykorzystaniu mikrobiologicznego ogniwa paliwowego $\mathrm{z}$ katodą $\mathrm{Cu}$-B [opracowanie własne]

Fig. 6. Change of concentration of $\mathrm{NH}_{4}{ }^{+}$during wastewater treatment with aeration and with using a microbial fuel cell with $\mathrm{Cu}-\mathrm{B}$ cathode [own compilation]

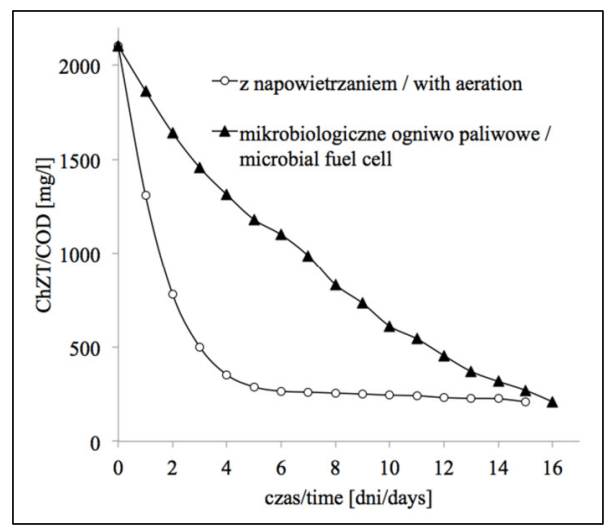

Rys. 5. Zmiana stężenia ChZT podczas oczyszczania ścieków z napowietrzaniem oraz przy wykorzystaniu mikrobiologicznego ogniwa paliwowego z katodą $\mathrm{Cu}$-B [opracowanie własne]

Fig. 5. Change of concentration of COD during wastewater treatment with aeration and with using a microbial fuel cell with $\mathrm{Cu}-\mathrm{B}$ cathode [own compilation]

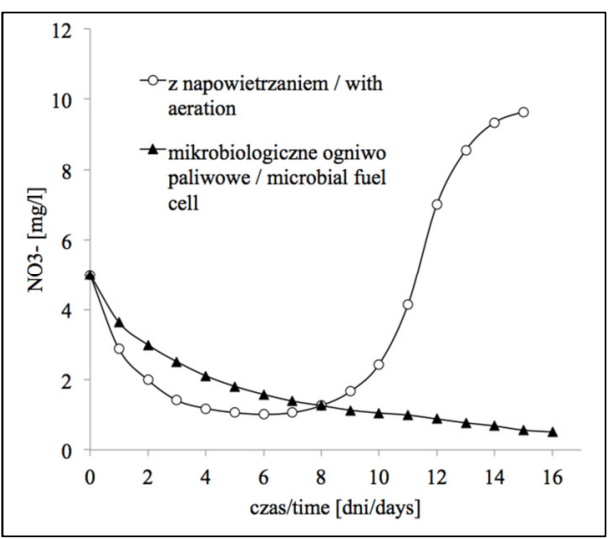

Rys. 7. Zmiana stężenia $\mathrm{NO}_{3}{ }^{-}$podczas oczyszczania ścieków z napowietrzaniem oraz przy wykorzystaniu mikrobiologicznego ogniwa paliwowego z katodą $\mathrm{Cu}-\mathrm{B}$ [opracowanie własne]

Fig. 7. Change of concentration of $\mathrm{NO}_{3}{ }^{-}$during wastewater treatment with aeration and with using a microbial fuel cell with $\mathrm{Cu}-\mathrm{B}$ cathode [own compilation] 


\section{Dyskusja wyników i wnioski}

Pomiary wykazały skuteczność usuwania ChZT na poziomie 90\% zarówno w przypadku napowietrzania jak i wykorzystania MFC. Również czas uzyskania tej wartości był zbliżony (rys. 5). W serii pomiarów oczyszczania ścieków komunalnych z napowietrzaniem największą szybkość usuwania ChZT uzyskano w pierwszych czterech dniach pomiaru. Redukcja ChZT przy wykorzystaniu ogniwa paliwowego następowała równomiernie podczas całego cyklu. Dla serii pomiarów dotyczących zmian stężeń $\mathrm{NH}_{4}^{+}$wykazano, że praktycznie wyeliminowano ten parametr tylko w przypadku napowietrzania ścieków. W serii pomiarów z wykorzystaniem mikrobiologicznego ogniwa paliwowego nie odnotowano praktycznie zmian stężenia $\mathrm{NH}_{4}{ }^{+} \mathrm{W}$ czasie. W pomiarach zmian wartości stężeń $\mathrm{NO}_{3}^{-}$w czasie wykazano, że w serii pomiarów z mikrobiologicznym ogniwem paliwowym wartość stężenia $\mathrm{NO}_{3}{ }^{-}$zredukowano o $91 \%$ (w czasie 16-u dni). Wzrost stężenia $\mathrm{NH}_{4}{ }^{+}$podczas napowietrzania wynika z przyłączania jonu wodorowego do cząstki amoniaku (np. w wyniku procesu gnilnego) [18-20], natomiast wzrost stężenia $\mathrm{NO}_{3}{ }^{-}$(rys. 6 i rys. 7) jest wynikiem procesu nitryfikacji podczas rozwoju bakterii [21, 22]. Uzyskana w MFC ilość energii jest niewielka $(0,87 \mathrm{Wh})$, jednak wykorzystanie MFC pozwoliłoby na całkowite zaoszczędzenie energii potrzebnej do napowietrzania zbiorników. Wyniki przeprowadzonych badań wykazały, że istnieje możliwość zastosowania stopu $\mathrm{Cu}-\mathrm{B}$ jako katalizatora katody w mikrobiologicznym ogniwie paliwowym do oczyszczania ścieków komunalnych.

\section{Literatura}

[1] Logan B.E.: Microbial fuel cell, John Wiley \& Sons, 2007.

[2] Logan B.E., Hamelers B., Rozendal R., Schrorder U., Keller J., Freguia S., Aelterman P., Verstraete W., Rabaey K.: Microbial fuel cells: Methodology and technology. Environmental Science \& Technology. v.40, 2006, pp.5181-5192.

[3] Rabaey K., Verstraete W.: Microbial fuel cells: novel biotechnology from energy generation. Trends Biotechnol. 23, 2005, pp.291-298.

[4] Kim H.J., Park H.S., Hyun M.S., Chang I.S., Kim M., Kim B.H.: A mediator-less microbial fuel cell using a metal reducing bacterium, Shewanella putrefacians. Enzyme Microbiol. Technol., 30, 2002, pp.145-152.

[5] Park H.S., B.H. Kim B.H., Kim H.S., Kim H.J., Kim G.T., Kim M., Chang I.S., Park Y.K., Chang H.I.: A novel electrochemically active and Fe(III)-reducing bacterium phylogenetically related to Clostridium butyricum isolated from a microbial fuel cell. Anaerobe, 7, 2001, pp.297-306.

[6] Allen R.M., Benetto H.P.: Microbial Fuel Cells: electricity production from carbohydrates. Appl. Biochem. Biotech., 39, 1993, pp.27-40.

[7] Chaudhuri S.K., Loveley D.R.: Electricity generation by direct oxidation of glucose in mediatorless microbial fuel cells. Nat. Biotechnol. v.21, 2003, pp.1229-1232. 
[8] Bond D.R., Lovley D.R.: Electricity production by Geobacter sulfurreducens attached to electrodes, Appl. Environ. Microbiol., 69, 2003, pp.1548-1555.

[9] Liu H., Cheng S., Logan B.E.: Production of electricity during wastewater treatment using a single chamber microbial fuel cell. Environ. Sci. Technol. 38, 2004, pp.22812285.

[10] Logan B.E.: Biologically extracting energy from wastewater: biohydrogen production and microbial fuel cells. Environ. Sci. Technol. 38, 2004, pp.160A-167A.

[11] Rabaey K., Aelterman P., Clauwaert P., L. De Schamphelaire, Boon N., Verstraete W.: Microbial fuel cells in relations to conventional anaerobic digestion technolog engineering in Life Sciences, 6, 2006, pp.285-292.

[12] Włodarczyk B., Włodarczyk P.P.: Electricity production in microbial fuel cell with $\mathrm{Cu}-\mathrm{B}$ alloy as catalyst of anode, QUAESTI-Virtual Multidisciplinary Conference, 3 (1), 2015, pp.305-308. DOI: 10.18638/quaesti.2015.3.1.211.

[13] Włodarczyk P.P., Włodarczyk B.: Electrooxidation of hydrazine with copper boride catalyst, Conference proceedings, 21st International Congress of Chemical and Process Engineering CHISA, P1.131, 2014.

[14] Włodarczyk P.P., Włodarczyk B.: Analysis of the possibility of using stainless steel and copper boride alloy as catalyst for microbial fuel cell fuel electrode, Archiwum Gospodarki Odpadami i Ochrony Środowiska, 17 (1), 2015, pp.111-118.

[15] Huggins T., Fallgren P.H., Jin S., Ren Z.J.: Energy and performance comparison of microbial fuel cell and conventional aeration treating of wastewater, J. Microb. Biochem. Technol., S6:002, 2013. DOI:10.4172/1948-5948.S6-002.

[16] Włodarczyk B., Włodarczyk P.P.: Porównanie skuteczności elektroutleniania w mikrobiologicznym ogniwie paliwowym z katalizatorem stalowym i napowietrzania w oczyszczaniu ścieków, Inżynieria i Ochrona Środowiska, 18 (2), 2015, pp.189198.

[17] Sumner J.J., Creager S.E., Ma J.J.: DesMarteau D.D, Proton Conductivity in Nafion 117 and in a Novel Bis[(perfluoroalkyl)sulfonyl]imide Ionomer Membrane, J. Electrochem. Soc., 145 (1), 1998, pp. 107-110. DOI: 10.1149/1.1838220.

[18] Bielański A.: Chemia ogólna i nieorganiczna, Państwowe Wydawnictwo Naukowe, 1981.

[19] Bielański A.: Podstawy chemii nieorganicznej, Wydawnictwo Naukowe PWN, 2013.

[20] Schweda E.: Chemia nieorganiczna, Wydawnicttwo Medpharm, 2014.

[21] Łomotowski J., Szpindor A.: Nowoczesne systemy oczyszczania ścieków, Arkady, 2002.

[22] Ren Z., Yan H., Wang W., Mench M.M., Regan J.M.: Characterization of microbial fuel cells at microbially and electrochemically meaningful time scales, Environ. Sci. Technol., 45 (6), 2011, pp.2435-2441. 


\section{MICROBIAL FUEL CELL WITH Cu-B CATHODE}

\section{S u m m a r y}

In microbial fuel cell as electrode are used carbon cloth (or carbon cloth with $1 \% \mathrm{Pt}$ ) electrodes are most common. The paper presents an analysis of the possibilities of using $\mathrm{Cu}-\mathrm{B}$ alloy as cathode catalyst in microbial fuel cells. The measurements included a preparation of catalyst, analysis of its activity in reduction $\mathrm{H}_{2} \mathrm{O}_{2}$ and comparison of changes in the concentration of COD, $\mathrm{NH}_{4}{ }^{+}$oraz $\mathrm{NO}_{3}{ }^{-}$in the reactor with aeration and with using a microbial fuel cell (with $\mathrm{Cu}-\mathrm{B}$ cathode). The reduction time for $\mathrm{COD}$ with the use of microbial fuel cell with the $\mathrm{Cu}-\mathrm{B}$ catalyst is similar to the reduction time with aeration. The obtained current density $\left(0.21 \mathrm{~mA} / \mathrm{cm}^{2}\right)$ and amount of energy are low $(0.87 \mathrm{Wh})$, but this power was obtained in small reactor (151). However, the obtained amount of energy allows elimination of the energy needed for reactor aeration. It has been shown that the $\mathrm{Cu}-\mathrm{B}$ can be used as cathode catalyst in microbial fuel cell.

Keywords: microbial fuel cell, catalyst, $\mathrm{Cu}-\mathrm{B}$ alloy, cathode, environmental engineering, renewable energy sources

DOI:10.7862/rb.2016.236

Przestano do redakcji: 03.06.2016 $r$.

Przyjęto do druku: 30.11.2016 r. 